\title{
Linkage analysis of myotonic dystrophy and sequences on chromosome 19 using a cloned complement 3 gene probe
}

\author{
K E DAVIES*, J JACKSON*, R WILLIAMSON*, P S HARPER $\dagger$, S BALL + , \\ M SARFARAZI $\dagger$, L MEREDITH $\dagger$, AND G FEY
}

From *the Department of Biochemistry, St Mary's Hospital Medical School, London; $\dagger$ Section of Medical Genetics, Welsh National School of Medicine, Cardiff; $\ddagger_{\ddagger}$ the Galton Laboratory, Department of Genetics and Biometry, University College London; and § Scripps Clinic and Research Foundation, La Jolla, California 92037, USA.

SUMMARY Variations in DNA sequence generate polymorphisms which can be followed through families. A cloned gene specific probe for human complement 3 (C3) was hybridised to DNA samples digested with restriction endonucleases. The $C 3$ probe detects several restriction fragment length polymorphisms (RFLPs) that occur frequently in the general population. These DNA alleles can be readily used in linkage analyses of loci on chromosome 19, since most families studied are informative. The inheritance of one such polymorphism was followed through myotonic dystrophy families. The segregation data for both the C3 protein polymorphism and the C3 RFLP support the linkage of myotonic dystrophy $(D M)$ and $C 3$.

Differences in DNA sequence owing to single base changes, deletions, or insertions occur approximately once in every 100 to 200 base pairs in the normal population $^{1}$ and may be detected as changes in the size of fragments generated after digestion of the DNA with restriction endonucleases. ${ }^{2}$ These restriction fragment length polymorphisms (RFLPs) show Mendelian inheritance and so can be used in family linkage studies to localise a specific gene of interest. ${ }^{3-7}$

If a linked restriction site polymorphism shows disequilibrium with a phenotype, as in sickle cell anaemia, then an analysis of the inheritance of the RFLP may also allow antenatal diagnosis of the disease. ${ }^{8}$ Diagnosis will also be possible if the mutation causing a disease generates a change in restriction pattern, ${ }^{9}$ or if a family study reveals a RFLP which shows linkage to a disease within the family even if in equilibrium in the population, as for some cases of thalassaemia. ${ }^{10}$

Myotonic dystrophy (DM) is a dominantly inherited disorder affecting about 1 in 8000 people in well studied populations. ${ }^{11}$ Although the age of onset of the disease is very variable, it manifests its symptoms mostly in adult life after the carriers have reached reproductive age. As yet there is no direct antenatal

Received for publication 8 February 1983. Accepted for publication 9 February 1983. diagnosis. Linkage analysis using protein polymorphisms has established that the $D M$ locus lies in the linkage group on chromosome 19 containing the loci for the Lutheran blood group and the ABH secretor system, ${ }^{12-14}$ the Lewis blood group, ${ }^{15}$ the C3 complement component, ${ }^{16}{ }^{17}$ and the enzyme peptidase $\mathrm{D} \cdot{ }^{18-20}$ In this paper, we describe the characterisation of common RFLPs detected by the DNA probe for $C 3$ that can be used in the genetic mapping of chromosome 19 , one of which gives a positive lod score with $D M$ in the first few families studied.

\section{Materials and methods}

FAMILY STUDIES

Families with myotonic dystrophy likely to be suitable for linkage investigations were selected from a large number of kindreds previously studied throughout the UK. All affected persons and relatives were examined clinically to confirm the diagnosis, including ophthalmoscopic examination using a portable slit lamp (KOWA instruments). In the case of unaffected relatives, only those over 20 years old were included in the DM linkage analysis to minimise the misidentification of late onset subjects. 
GENE PROBE FOR C 3

The C3 DNA probe consists of a non-repetitive sequence, most likely an exon of the structural gene coding for this protein. ${ }^{17}$ The sequence, a PstI fragment $1.39 \mathrm{~kb}$ in length (1 kilobase $(\mathrm{kb})$ equals 1000 base pairs of DNA), was cloned into pxf 3 , a derivative of $\mathrm{pBR} 322$. All recombinants were grown under conditions advised by GMAG.

\section{H Y BR IDISATION}

DNA was isolated from blood samples taken from patients and their families. ${ }^{21}$ DNA was digested to completion with restriction enzymes and electrophoresed in $0.8 \%$ agarose gels. The gels were blotted onto nitrocellulose filters ${ }^{22}$ and hybridised to nick-translated $C 3$ probe as described previously. ${ }^{23}$ The filters were autoradiographed for 18 hours at $-70^{\circ} \mathrm{C}$.
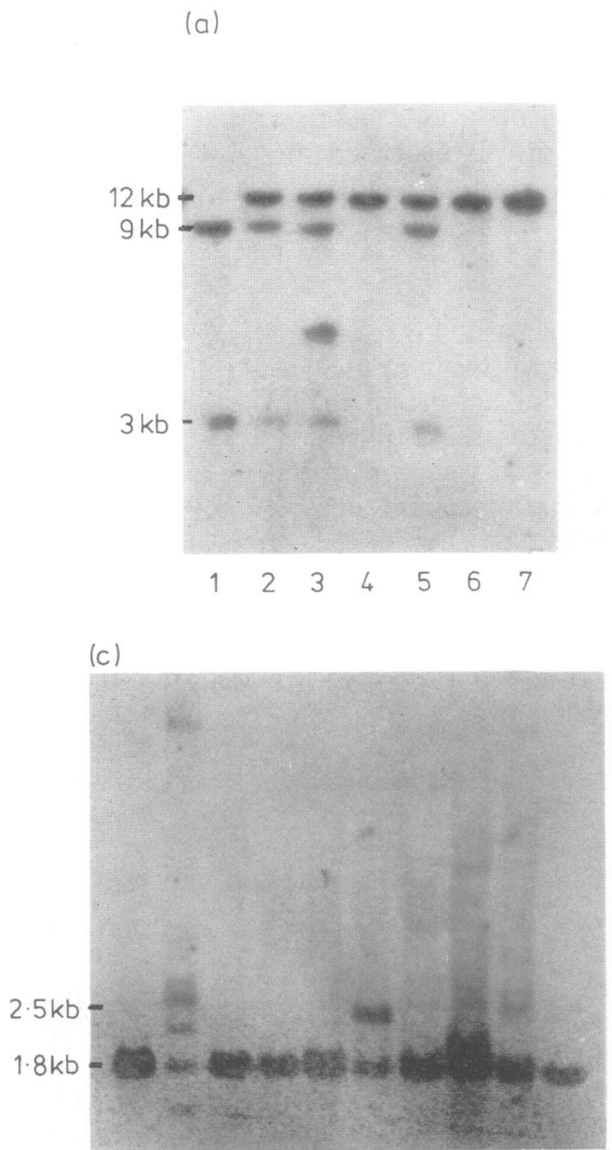

C3 PROTEIN ANALYSIS

The C3 plasma protein polymorphism was typed by high voltage agarose gel electrophoresis using fresh plasma or plasma stored at $-20^{\circ} \mathrm{C}$ for up to one week. The bridge buffer was $50 \mathrm{mmol} / \mathrm{l}$ barbital buffer $\mathrm{pH} 8.6$ containing $1.8 \mathrm{mmol} / \mathrm{l}$ calcium lactate and then diluted $1: 1$ with distilled water for the gel buffer. One percent agarose gel was prepared using Litex agarose (Denmark) type HSB and poured onto alcohol washed $220 \times 150 \times 3 \mathrm{~mm}$ glass plates to form a layer $1.25 \mathrm{~mm}$ thick. Up to 12 slots for plasma application were cut using $4 \mathrm{~mm}$ wide strips of Whatman No 3 paper and placed about $40 \mathrm{~mm}$ from the cathode end of the gel. A total of $3 \mu \mathrm{l}$ of plasma was placed in each slot. Electrophoresis was carried out at $20 \mathrm{~V} / \mathrm{cm}$ for 2 hours at $5^{\circ} \mathrm{C}$. Gels were stained for protein using $0.1 \%$ Coomassie Blue. ${ }^{24}$

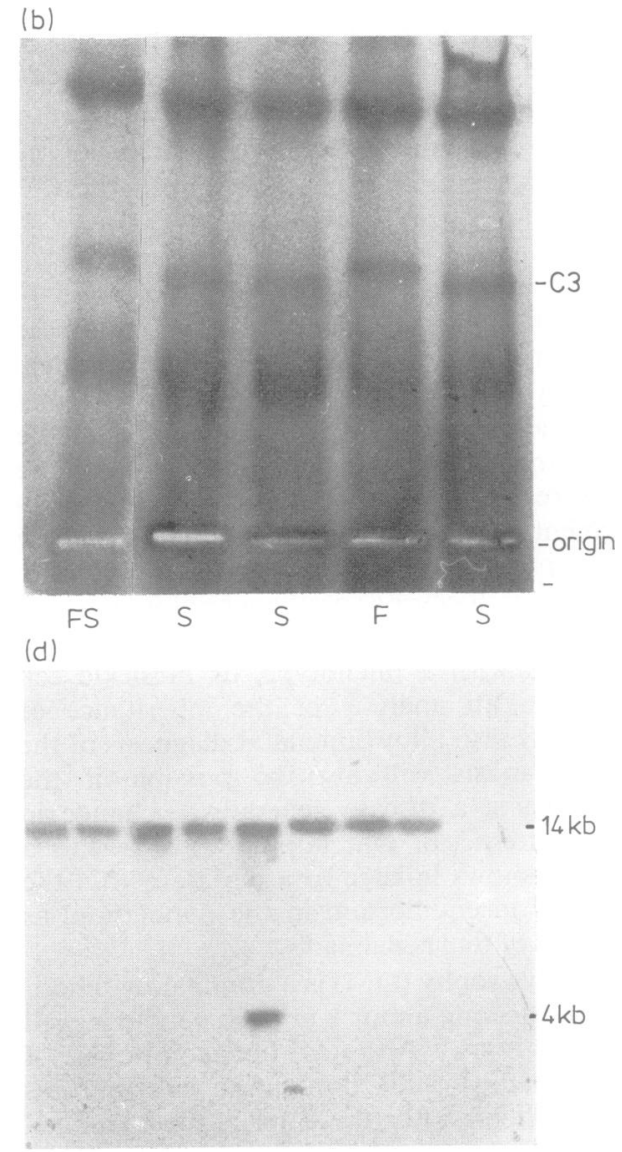

FIG 1 Restriction enzyme fragment length polymorphisms detected by a C3 probe with the enzymes SstI (a), TaqI (c), and BgIII $(d)$. Southern blots were washed to $3 \times S S C$ and autoradiographed for 18 hours at $-70^{\circ} \mathrm{C}$. Fig $1 \mathrm{~b}$ shows the stained $C 3$ protein gel. 


\section{Results}

DNA samples from both normal subjects and members of myotonic dystrophy families show DNA sequence polymorphisms with the gene specific probe for $C 3$, using the restriction endonucleases SstI, TaqI, and BglII (fig la, c, d). The polymorphism used in this study, detected after digestion by the enzyme SstI, gives three patterns: a single $12.0 \mathrm{~kb}$ fragment, two fragments of $9.0 \mathrm{~kb}+3.0 \mathrm{~kb}$, or all three fragments (lanes 6, 1 , and 2 in fig 1a). These patterns are interpreted to be the result of the products of two alleles, $A I$ and $A 2$. The frequency of the rarer allele $(A 2)$ in the random population is $0 \cdot 36$, which is similar to the frequency found in the myotonic dystrophy patients (table 1). Fig $1 \mathrm{~b}$ shows the three $\mathrm{C} 3$ phenotypes FS, S, and F (lanes 1, 2, and 4 ) detected by electrophoresis. The frequency of the rarer allele $(F)$ in the random population is $0 \cdot 22$.

Fig 2 shows a myotonic dystrophy pedigree in which both DNA and protein polymorphism are

TABLE 1 Comparison of gene frequencies of the C3 protein polymorphism and RFLP in the random UK population and unrelated myotonic dystrophy patients. (*Galton Laboratory, unpublished data.)

\begin{tabular}{|c|c|c|c|c|c|}
\hline \multirow[t]{2}{*}{$C 3 R F L P$} & \multicolumn{3}{|c|}{ Phenotypes } & \multicolumn{2}{|c|}{ Gene frequencies } \\
\hline & $A I$ & $A 1 A 2$ & $A 2$ & $A l$ & $A 2$ \\
\hline \multirow[t]{2}{*}{$\begin{array}{l}\text { Normal population } \\
\text { DM patients }\end{array}$} & $\begin{array}{r}19 \\
2\end{array}$ & $\begin{array}{r}21 \\
8\end{array}$ & $\begin{array}{l}6 \\
2\end{array}$ & $\begin{array}{l}0 \cdot 64 \\
0 \cdot 50\end{array}$ & $\begin{array}{l}0 \cdot 36 \\
0 \cdot 50\end{array}$ \\
\hline & & & \multicolumn{3}{|c|}{${\chi_{(1)}^{2}}^{2}=1 \cdot 6, p>0 \cdot 20$} \\
\hline \multirow{2}{*}{$\begin{array}{l}\text { C3 protein } \\
\text { polymorphism* }\end{array}$} & \multicolumn{3}{|c|}{ Phenotypes } & \multicolumn{2}{|c|}{ Gene frequencies } \\
\hline & $S$ & $F S$ & $F$ & $S$ & $F$ \\
\hline $\begin{array}{l}\text { Normal population } \\
\text { DM patients }\end{array}$ & $\begin{array}{r}380 \\
26\end{array}$ & $\begin{array}{r}216 \\
14\end{array}$ & $\begin{array}{r}34 \\
2\end{array}$ & $\begin{array}{l}0 \cdot 77 \\
0 \cdot 79\end{array}$ & $\begin{array}{l}0 \cdot 23 \\
0 \cdot 21\end{array}$ \\
\hline \multicolumn{6}{|c|}{$\psi_{(1)}^{2}=0.05, p>0.70$} \\
\hline
\end{tabular}

MRC 4937, M92

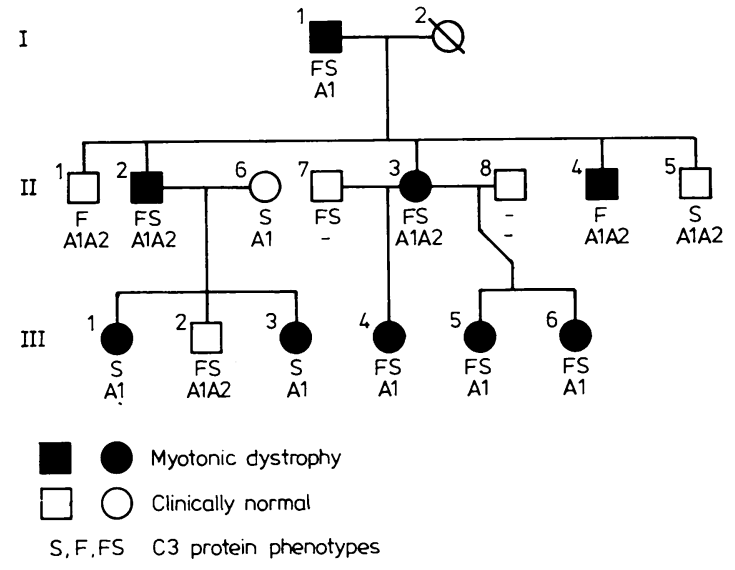

A1,A2,A1A2 C3 RFLP types

FIG 2 Pedigree of family MRC 4937, M92 showing the segregation of myotonic dystrophy, the $C 3$ protein polymorphism, and the C3 RFLP. (The numbering is consistent with that used in ref 20.)

segregating; both show codominant inheritance. We have found no evidence for recombination between the $C 3 \mathrm{RFLP}$ and the protein polymorphism.

Linkage between the $C 3$ RFLP, the protein polymorphism, and myotonic dystrophy was analysed by the computer programme LIPED, ${ }^{25}$ using the variable age of onset factor curve ${ }^{11}$ (table 2). In calculating the total lod score, subjects heterozygous for both the RFLP and protein polymorphisms were included only once. For example, in family M92 (fig 2), I.1 was scored for the C3 protein polymorphism, and II.2 and II.3 were both scored for the C3 RFLP as they are phase known, whereas phase is not known for the C3 protein polymorphism.

TABLE 2 Lod scores between myotonic dystrophy and the C3-RFLP and protein polymorphisms.

\begin{tabular}{|c|c|c|c|c|c|c|c|c|c|c|}
\hline & \multirow[t]{2}{*}{ Sex } & \multicolumn{3}{|c|}{ Children } & \multicolumn{6}{|c|}{ Lod scores at various values of 0} \\
\hline & & No & $r c$ & $n r c$ & $0.0 I$ & 0.05 & $0 \cdot 10$ & $0 \cdot 20$ & $0 \cdot 30$ & $0 \cdot 40$ \\
\hline \multirow[t]{2}{*}{$D M: C 3-$ RFLP } & $\mathbf{P}$ & 9 & 0 & 4 & -0.90 & +0.83 & +0.74 & +0.57 & +0.39 & $+0 \cdot 20$ \\
\hline & $\mathbf{M}$ & 13 & 2 & 3 & $-4 \cdot 60$ & -1.93 & -0.98 & $-0 \cdot 22$ & +0.03 & +0.08 \\
\hline \multirow[t]{2}{*}{$D M: C 3$-protein } & $\mathbf{P}$ & 22 & 0 & 1 & +0.36 & +0.98 & $+1 \cdot 10$ & +0.93 & +0.58 & $+0 \cdot 21$ \\
\hline & $\mathbf{M}$ & 19 & 0 & 1 & $-1 \cdot 94$ & -0.80 & -0.26 & +0.12 & +0.17 & $+0 \cdot 10$ \\
\hline \multirow[t]{2}{*}{$D M: C 3$ total } & $\mathbf{P}$ & 22 & 0 & 4 & $+1 \cdot 22$ & -1.68 & +1.68 & $+1 \cdot 34$ & +0.86 & +0.38 \\
\hline & $\mathbf{M}$ & 29 & 2 & 4 & 6.62 & $-2 \cdot 84$ & $-1 \cdot 30$ & -0.13 & +0.18 & $+0 \cdot 17$ \\
\hline \multicolumn{11}{|l|}{$D M: C 3$} \\
\hline \multirow[t]{2}{*}{ Eiberg et $a^{16}$} & $\mathbf{P}$ & 16 & 0 & 0 & & $+1 \cdot 68$ & $+1 \cdot 63$ & $+1 \cdot 21$ & +0.67 & +0.06 \\
\hline & $\mathbf{M}$ & 6 & 0 & 0 & & $-1 \cdot 18$ & -0.67 & -0.25 & -0.09 & -0.02 \\
\hline \multirow[t]{2}{*}{ Total } & $\mathbf{P}$ & 38 & 0 & 4 & & $+3 \cdot 36$ & $+3 \cdot 31$ & +2.55 & +1.53 & +0.44 \\
\hline & $\mathbf{M}$ & 35 & 2 & 4 & & -4.02 & -1.97 & -0.38 & +0.09 & +0.15 \\
\hline
\end{tabular}

$\mathbf{P}=$ paternal double heterozygote.

$\mathbf{M}=$ maternal double heterozygote.

No $=$ number scored.

$\mathrm{rc}=$ recombinants.

nrc $=$ non-recombinants. 


\section{Discussion}

Our study is in agreement with the linkage between C3 and myotonic dystrophy previously suggested by Eiberg and Mohr ${ }^{16}$ based on the protein polymorphism alone. So far we have not studied all the families for the C3 RFLP, but such a combined approach will considerably increase the proportion of families from which linkage data can be obtained. As expected, no example of recombination was found between the site defined by the C3 DNA probe and the $\mathrm{C} 3$ protein.

Our data show a marked difference in recombination fraction for male and female recombination (table 2), a rather general finding in human linkage, also found previously for the C3 protein polymorphism. ${ }^{16}$ For a marker to be of general use for antenatal diagnosis of myotonic dystrophy it must show linkage in both males and females. The genetic length of chromosome 19 in males is about $100 \mathrm{cM}^{26} 27$ and the female genetic length may well be greater than $200 \mathrm{cM}$. Therefore, at least ten equally spaced markers will be required to permit the construction of a total genetic linkage map of chromosome 19.

The $C 3$ and $D M$ loci are at a considerable distance (of the order of $7 \mathrm{cM}$ in males and much greater in females). Since the total DNA sequence length of the human haploid genome is approximately $3 \times 10^{9}$ bp (or $3 \times 10^{6} \mathrm{~kb}$ ), ${ }^{27}$ and since the male genetic length is 33 Morgans, ${ }^{28} 29$ one centiMorgan is approximately equal to $1000 \mathrm{~kb}$ for males. Therefore the $C 3$ probe is at least $7000 \mathrm{~kb}$ from the DM defect, too far to 'walk' along the chromosome. ${ }^{30}$ It is necessary to isolate further probes defining sites closer to myotonic dystrophy before 'walking' from a close-by site to the disease locus becomes feasible.

The authors thank the Medical Research Council, Cystic Fibrosis Research Trust, UK Muscular Dystrophy Group, and the US Muscular Dystrophy Association for research grants supporting this work. We thank Mrs P Taylor and Miss S McGlade for technical assistance, and Professor E B Robson for useful discussions and suggestions during the preparation of this manuscript.

\section{References}

1 Jeffreys AJ. DNA sequence variants in the $\mathrm{G}_{\gamma-}, \mathrm{A} \gamma-, \delta$ - and $\beta$-globin genes of man. Cell 1979;18:1-10.

2 Davies KE. The application of DNA recombinant technology to the analysis of the human genome and genetic disease. Hum Genet 1981;58:351-7.

3 Hill MEE, Davies KE, Harper PS, Williamson R. The Mendelian inheritance of a human $\mathrm{X}$ chromosome- specific DNA sequence polymorphism and its use in linkage studies of genetic disease. Hum Genet 1982;60: 222-6.

4 Solomon E, Bodmer WF. Evolution of sickle variant gene. Lancet $1979 ; \mathrm{i}: 92$.

5 Botstein D, White RI, Skolnick M, Davis RW. Construction of a genetic linkage map in man using restriction fragment length polymorphisms. Am J Hum Genet $1980 ; 32: 314-31$.

6 Murray JM, Davies KE, Harper PS, Meredith L, Mueller CR, Williamson $R$. Linkage relationship of a cloned DNA sequence on the short arm of the X chromosome to Duchenne muscular dystrophy. Nature 1982; 300:69-71.

7 Shows TB, Sakaguchi AY, Naylor SL. Mapping the human genome, cloned genes, DNA polymorphisms and inherited disease. Adv Hum Genet 1982;12:341-452.

8 Kan YW, Dozy AM. Polymorphism of DNA sequence adjacent to the human $\beta$-globin structural gene: relationship to sickle mutation. Proc Natl Acad Sci USA 1978; 75:5631-5.

- Wilson JT, Milner PF, Summer ME, et al. Use of restriction endonucleases for mapping the allele for $\beta$-globin. Proc Natl Acad Sci USA 1982;79:3628-31.

10 Little PFR, Flavell RA, Kooter JM, Annison G, Williamson R. Structure of the human fetal globin gene locus. Nature 1979;278:227-31.

11 Harper PS. Myotonic dystrophy. Philadelphia: Saunders, 1979.

12 Mohr J. A study of linkage in man. Opera ex Domo C Biologiae Hereditariae Humanae Universitatis Hafniensis 33. Copenhagen: Munksgaard, 1954.

13 Renwick JH, Bundey SE, Ferguson-Smith MA, Izatt MM Confirmation of linkage of the loci for myotonic dystrophy and ABH secretion. $J$ Med Genet 1971;8: 407-16.

14 Harper PS, Rivas ML, Bias WB, Hutchinson JR, Dyken PR, McKusick VA. Genetic linkage confirmed between the locus for myotonic dystrophy and the ABHsecretion and Lutheran blood group loci. Am J Hum Genet $1972 ; 24: 310-6$.

15 Simola K, de la Chapelle A, Pirkola A, Karli P, Cook PJL, Tippett PA. Data on DM-Le linkage. Human gene mapping 6 (1981). Sixth International Workshop on Human Gene Mapping. Birth Defects 1982;18: No 2.

16 Eiberg H, Mohr J, Staub Nielsen L, Simonsen N. Linkage relationship between the locus for $\mathrm{C} 3$ and 50 polymorphic systems: assignment of $\mathrm{C} 3$ to the DM-SE- o LU linkage group: confirmation of C3-LES linkage; support of LES-DM synteny. Proc VI Int Cong Hum Genet, Jerusalem, 1981. New York: Liss, 1982.

17 Whitehead AS, Solomon E, Chambers S, Bodmer WF, D Povey S, Fey G. Assignment of the structural gene for the third component of human complement to chromosome 19. Proc Natl Acad Sci USA 1982;79:5021-5.

18 Cook PJL, Povey S, Robson EB. Linkage studies on peptidases A, B, C and D in man. Ann Hum Genet 1972; 36:89-97.

19 McAlpine PJ, Mohandas T, Ray M, Wang H, Hamerton J. $O$ Assignment of the peptidase D locus to chromosome 19 in man. Third International Workshop on Human Gene Mapping (1975). Birth Defects 1975;X11,7:204-5.

20 O'Brien T, Ball S, Sarfarazi M, Harper PS, Robson EB. $\stackrel{?}{+}$ Genetic linkage between the loci for myotonic dystrophy $\square$ and peptidase D. Ann Hum Genet 1983;47:117-21.

21 Kunkel LM, Tantravahi U, Eisenhard M, Latt SA. Regional localisation on the human X of DNA sequences cloned from flow sorted chromosomes. Nucleic Acids Res $1982 ; 10: 1557-61$. 
22 Southern E. Detection of specific sequences among DNA fragments separated by gel electrophoresis. $\mathrm{J} \mathrm{Mol} \mathrm{Biol}$ 1975 ;98:503-17.

23 Davies KE, Young BD, Elles RG, Hill ME, Williamson R. Cloning of a representative genomic library of the human $\mathrm{X}$ chromosome after sorting by flow cytometry. Nature $1981 ; 293: 374-6$.

24 Berg K, Noer G, Heiberg A. Studies on the genetic polymorphism of the C3 of human serum. Clin Genet $1970 ; 1: 177-80$.

25 Ott J. Estimation of the recombination fraction in human pedigrees: efficient computation of the likelihood for human linkage studies. Am J Hum Genet 1974;26:588-97.

26 Keats BJB, Morton NE, Rao DC, Williams WR. A source book for linkage in man. Baltimore, London: Johns Hopkins University Press, 1979:213.

27 Cook PJL, Noades JE, Lomas CG, Buckton KE,
Robson EB. Exclusion mapping illustrated by the MNSs blood group. Ann Hum Genet 1980;44:61-73.

28 Vogel F. Sind die Mutationsraten fur die X-chromosomal rezesswein Hamophiliformen in Keimzellen von Frauen niedriger als in Keimzellen von Mannern? Humangenetik $1965 ; 1: 253-63$

29 Renwick JH. The mapping of human chromosomes. Ann Rev Genet $1971 ; 5: 81-120$.

30 Dahl HH, Flavell RA, Grosveld FG. The use of genomic libraries for the isolation and study of eukaryotic genes. In: Williamson R, ed. Genetic Engineering 2. London: Academic Press, 1982:50-127.

Correspondence and requests for reprints to Dr K E Davies, Department of Biochemistry, St Mary's Hospital Medical School, London W2 1PG. 